\title{
The Netherworld between Work and Retirement
}

\section{Michael McGann*, Helen Kimberley**, Dina Bowman*** and Simon Biggs}

\author{
* School of Social and Political Sciences, University of Melbourne \\ E-mail:mmcgann@unimelb.edu.au \\ ** Research and Policy Centre, Brotherhood of St Laurence \\ E-mail: hkimberley@bsl.org.au \\ ${ }^{* * *}$ Research and Policy Centre, Brotherhood of St Laurence, School of Social and Political Sciences, University of \\ Melbourne \\ E-mail: dbowman@bsl.org.au
}

**** School of Social and Political Sciences, University of Melbourne

E-mail: biggss@unimelb.edu.au

A major theme within social gerontology is how retirement is being re-organised, if not undone'. Institutional supports for retirement are weakening, with pension ages rising in many countries. Increasing numbers of older workers are working past traditional retirement age on a part-time or self-employed basis, and a growing minority are joining the ranks of the long-term unemployed. Drawing upon narrative interviews with older Australians who are involuntarily non-employed or underemployed, this article explores how the 'unravelling' of retirement is experienced by a group of older workers on the periphery of the labour market. While policy makers hope that higher pension ages will lead to a longer period of working life, the risk is that older workers, especially those experiencing chronic insecurity in the labour market, will be caught in a netherworld between work and retirement.

Keywords: older workers, long-term unemployment, early exit, precarity.

\section{Introduction}

The relationship between work and ageing is undergoing a profound reorganisation, enveloped by a climate of risk and uncertainty. Where, for much of the later twentieth century, retirement denoted a predictable 'age-patterned end to working life' (Vickerstaff, 2006: 456) - at least for men ${ }^{1}$ - a major theme in social gerontology is how retirement 'is being re-organised, if not undone' (Han and Moen, 1999: 196). There is much discussion about how retirement is being 're-imagined and reinvented' (Farrell, 2014: 9) by baby boomers who are looking to retirement not as the beginning of the end but as an opportunity to continue their careers 'in a different venue and/or form' (Shultz and Wang, 2011: 177). This is reflected in the changing retirement expectations of older workers in Britain and Australia, with studies showing that many want to work beyond sixty-five on a flexible or part-time basis (McNair, 2006; Warren, 2008; Vickerstaff, 2010). It is important to note, however, that manual and low-skilled workers continue to see retirement as 'an intrinsically valued and necessary stage in the life-course' (Parry and 
Taylor, 2007: 595). As pension ages rise, amidst deepening fears of an impending pensions crisis and moral panic about the movement of baby boomers towards retirement (Moody, 2008), older workers are increasingly being urged to 'add ... life to longer years' (Commission of the European Communities, 1999: 21) by working longer. All this paints a relatively benign picture of how retirement 'is unravelling' (Sargent et al., 2013: 13) that suggests the emergence of a more flexible life-course less constrained by traditional institutions and chronological boundaries. However, this masks the diversity of older workers and the more precarious experiences of the growing minority 'experiencing chronic insecurity in the labour market' (Phillipson, 2015: 83), with almost a quarter of a million mature-age (forty-five plus) Australians receiving unemployment benefits in June 2015 (Department of Employment, 2015b).

Drawing on narrative interviews with involuntarily non-employed and underemployed older Australians, this article explores how the unravelling of retirement is being experienced by a group of older workers unwillingly caught between work and retirement: 'too old to work and too young to retire' (McGann et al., 2015). The experiences of such older workers are too frequently neglected in prevailing policy responses to population ageing, which Taylor (2013: 13-14) characterises as 'naive, perhaps even ageist, assuming as they do that a gradual winding down is an option or even advisable for many older people'. We first consider briefly the changing policy landscape surrounding retirement and the labour market situation of older workers. Some findings from a recent study are then introduced in the context of the potential for current policy directions to compound the precarity experienced by un(der)employed older workers who find themselves 'caught between insecure work on the one side and an increasingly insecure retirement on the other' (Phillipson, 2013: 457).

\section{Retirement and the labour market situation of older workers}

As Taylor (2010: 541) observes, older workers' fortunes 'have been and continue to be strongly influenced by the ebbs and flows of market forces and government policy'. In the late 1970s and 1980s, when unemployment was rising due to large-scale industrial restructuring and the entry of a large cohort of young baby boomers into the labour market, older workers were largely viewed as a 'reserve army' of labour. Early exit was seen as one of the 'bloodless' ways of coping with unemployment (Kohli and Rein, 1991: 11) during this period, and many countries introduced institutional pathways, such as the Job Release Scheme in the UK, to enable older workers who had not yet reached full pension age to leave employment (Guillemard, 1997). This produced a sharp decline in employment rates among older men in almost all industrial countries, including Australia, where the proportion of men aged fifty-five to sixty-four in employment fell from 67 per cent in 1979 to 59 per cent in 1990 (Taylor, 2010). This downward trend in older male employment continued into the mid-1990s, when a new 'moral narrative' (Phillipson, 2015: 91) on ageing and employment emerged.

With people living longer, but also spending longer in education and leaving the workforce at younger ages, the proportion of life spent in work was 'shrinking' (Vickerstaff, 2010: 869). As concerns started to grow about the fiscal 'burden' of ageing populations, major institutional players such as the European Union and Organisation for Economic Cooperation and Development began emphasising older people's capacity to 'lead productive lives in society and the economy' (OECD, 1998: 14, 84). Around this time, the World Bank also agressively pushed for countries to reduce expenditure on public pensions by expanding the role of private capitalised pensions as 'second pillars' of retirement funding. A related 'individualisation of retirement' (Vickerstaff and Cox, 2005: 92) occurred within occupational pensions, as more and more employers closed their defined benefit pension arrangements, replacing them with contributory schemes.

Employment rates among older workers have since risen in many countries, driven by markedly higher overall employment among older women but also rising part-time employment among older men 
(Ekerdt, 2010; Taylor, 2013). By 2007, 66 per cent of Australian men and 48 per cent of Australian women aged fifty-five to sixty-four were employed compared with 55 and 27 per cent, respectively, in 1995 (Taylor, 2010: 543). In other countries, particularly the US, the growth in employment (particularly parttime employment) among older workers over the late 1990s and early 2000s was celebrated as heralding 'a new phase of work in mid and later life' in which older adults were increasingly pursuing 'encore careers' (Freedman, 2006-07: 46) or switching to part-time or self-employment as bridges to retirement (Shultz and Wang, 2011). The impression was of a new 'voluntary and strategic' kind of job mobility for older workers, although as Ekerdt (2010: 75) cautions, rises in part-time employment may have equally been evidence of more frequent job displacements: 'the late-career expression of the episodic employment and shorter job tenures that have become generally common across adulthood'. Taylor (2010: 547), for example, notes that the increase in part-time employment among European older workers over 2000-05 was accompanied by an almost doubling of the number of older workers who were underemployed. More recently in Australia, there has been a similarly sharp increase in the numbers of underemployed mature-age workers from less than 214,000 in November 2008 to over 322,000 in November 2015 (ABS, 2015).

Although rates of participation are now higher than twenty years ago, the majority of older workers continue to leave employment before full pension age (Phillipson, 2015: 83). Many do so involuntarily through redundancy, with the global financial crisis (GFC) severely restricting their opportunities. In America, the unemployment rate among workers aged fifty and over more than doubled over 2007-10, while almost half of older American workers who lost their jobs during the recession were still unemployed a year later (Johnson, 2012: 3). In Europe, more than half of those aged fifty-five and over who were unemployed in 2010 had been unemployed for a year or more, with rates of unemployment among older men higher in 2010 than they were in the early 1990s in several countries, including Denmark, the Netherlands, Ireland and Spain (Taylor, 2013). While Australia is widely considered to have weathered the GFC relatively well, nevertheless, in June 2015, almost a quarter of a million mature-age jobseekers were receiving unemployment benefits or Newstart (Department of Employment, 2015b) compared with fewer than 155,000 in June 2008 (Department of Social Services, 2009). Of these, close to 70 per cent were long-term jobseekers who had been registered for social security for a year or more (Department of Employment, 2015a).

High rates of long-term unemployment among older workers are compounded by the pervasiveness of age-discrimination, which leads many older workers to become discouraged and to stop looking for work. According to research by the Australian Human Rights Commission (2015), around a quarter of Australians aged fifty and over experienced some form of work-related age-discrimination in 2013-14, with reports of discrimination highest among those looking for work. The Australian Bureau of Statistics (2014) data show that almost half of 'discouraged' mature-age Australians outside the labour force in September 2013 had stopped looking for work because they felt 'considered too old by employers'. Elsewhere in this issue, Bowman et al. highlight systemic barriers facing older jobseekers within employment services systems, including the young age of many employment services' staff (mid-twenties to early thirties), which can lead to unconscious bias and misrecognition of older jobseekers' capabilities and experience. The changing nature of work and the obsolescence of many older workers' skills have also been suggested as contributing to high rates of long-term unemployment among older jobseekers (Deeming and Smyth, this issue).

Research studies highlight the devastating effects that unemployment in mature-age can have on mental health, as individuals face the demise of their careers with a sense 'of being denied a decent ending' (Kohli and Rein, 1991: 27). This is reflected in the high levels of depression reported in empirical studies by those who experience involuntary exit (for a review see Hershey and Henkens, 2013), with participants in qualitative research reporting feelings of 'anxiety, depression, guilt, anger, and sadness' (McDonald 
Table 1 Characteristics of participants

\begin{tabular}{lccc}
\hline \hline & $\begin{array}{c}\text { Women } \\
(n=43)\end{array}$ & $\begin{array}{l}\text { Men } \\
(n=37)\end{array}$ & $\begin{array}{l}\text { Total } \\
(n=80)\end{array}$ \\
\hline Age & & & \\
$45-54$ & 21 & 14 & 35 \\
$55-64$ & 16 & 15 & 31 \\
$65+$ & 6 & 8 & 14 \\
\hline Total & 43 & 37 & 80 \\
\hline Occupation & 14 & 17 & 31 \\
$\quad$ Managers or professionals & 4 & 8 & 12 \\
Trades workers and technicians & 0 & 1 & 1 \\
Machinery operators & 6 & 3 & 9 \\
Community and personal services workers & 18 & 6 & 24 \\
Clerical and administrative workers & 1 & 1 & 2 \\
Sales workers & 0 & 1 & 1 \\
$\quad$ Labourers & 43 & 37 & 80 \\
\hline Total & & & \\
\hline \hline
\end{tabular}

et al., 2000: 79). There are also the serious long-term financial effects associated with prolonged loss of earnings and reduced capacity to save for retirement, which, as Ranzijn et al. (2006: 474) observe, can lead to 'intense anxiety' among older unemployed workers 'about their ability to manage financially for the rest of their lives'.

\section{The Australia study}

The findings reported here are drawn from a recent study, Understanding and Preventing Workforce Vulnerabilities in Midlife and Beyond. The focus here is on the retirement and labour force experiences of a group of involuntarily non-employed and underemployed mature-age Australians, drawing on narrative interviews with eighty older Australians conducted as part of research on the complex ways in which people's labour market attachment weakens before 'retirement age'. The participants came from a range of occupational backgrounds (Table 1) in three areas of Eastern Australia with high levels of mature-age unemployment, and were recruited using advertisements placed in local libraries, public employment services and on-line jobsites for older workers, and with the assistance of older worker advocacy organisations.

Semi-structured phone interviews were conducted with all participants in 2013. In the interviews, participants were asked a series of questions about their experience of ageing and age identities. Questions also addressed their work histories and most recent experiences of looking for work, including their previous employment experiences; the sequencing of their transitions into, within and out-of employment; and the personal and social circumstances surrounding these transitions. In this way, the interview questions adopted a life-course perspective, situating interviewees' current labour market experiences within the context of past constraints and opportunities (McDaniel and Bernard, 2011). The interviews were recorded and transcribed. A sample of twenty transcripts, stratified by age and gender, were analysed manually by the authors and a series of categories and themes emerging from the data were agreed 
upon following an intensive workshop. NVivo software was used to manage the coding of the data, and transcripts were coded in depth until saturation point - the 'point in data collection and analysis when new information produces little or no change to the codebook' (Guest et al., 2006: 65) - which occurred after thirty-eight interviews. A further eight transcripts were coded to ensure the sample reflected the age, occupational and gender profile of interviewees.

Half the participants (twenty-two women; eighteen men) were re-interviewed to further explore key identified themes, including participants' perceptions of ageism, their experiences of employment services and their changing expectations about retirement. The findings reported here focus on their understandings and experiences of the fragmentation of retirement, which was widely commented upon in the interviews, although it affected different groups of participants in divergent ways that reflected occupational and age-related differences in their attachment to work. For example, several (seven) of the participants were managers or professionals in their late fifties or early sixties who had recently been made redundant. These older managers and professionals felt a sense of injustice about the way they had been retrenched, which caused them to question their previous level of commitment to their careers. Being without work for a sustained period had also unexpectedly given them an opportunity to (re)discover other sources of fulfilment that they had previously not had time to develop. With financial savings over long careers, work was less of a necessity for these jaded older workers who were looking to rebalance work in relation to the rest of their lives.

A second group of participants also prioritised the importance of balancing work around having time for other pursuits, although for different reasons. Nearly all women, many of whom had intermittent work histories as second income earners, the small minority of participants in this group described a shift in their perspective on working life that came from mature age. This included feeling more 'comfortable in [their] skin' and being less concerned with materialistic pursuits or fitting other people's expectations. They expressed a degree of ambivalence about the value of work and prioritised having time for themselves and avoiding the rushed experience of life that they associated with working fulltime. Most participants in the study, however, remained strongly attached to the labour market and could not envisage retiring at the traditional age of sixty-five. The findings reported below focus on the intersection between these participants' experiences of joblessness and their need, or desire, to keep working.

\section{Unravelling of work and retirement}

A common sentiment expressed by participants was that 'times have changed' (Neil, fifty-five), and, as a former HR manager who was working casually in a liquor store observed, the old days are gone where 'at sixty-five ... the orchestra plays and you live happily ever after without jobs' (lan, sixty-three). For some, this was a welcome development on the basis that they feared retirement would leave them with 'too much time' and that their health would 'start to deteriorate' (Jacinta, forty-six, administrative worker) upon retirement. For Kevin (fifty-three), a transcriber, '[t]he notion of vegging out at the age of sixty-five, going on an Age Pension and driving around' induced in him 'absolute horror' as he had 'seen so many people who looked forward to retirement and when retirement actually happened ... they went physically and mentally and morally to pieces'. In many ways, these participants' fears about what they would do in retirement echoed longstanding concerns about the potential for the loss of the work role to lead to an 'identity breakdown' (Havinghurst, 1954: 311) if the void left by work was not successfully filled. The comparatively young age of a number of these participants may have also made it more difficult for them to conceive retiring. However, a psychological resistance to retirement was also evident among several older (predominantly university-educated) participants who, often referencing their parents' experiences, 
sought to distance themselves from pensioner identities which they associated with 'turning into an old lady' (Eve, media sales, sixty-three) and being 'totally retired from life' (Margaret, HR manager, sixty-six):

I don't want to have forty years in retirement. That's just a waste of energy and brain space and productivity ... My mum's nearly 90. (Sarah, administrative worker, fifty-eight)

By contrast, a small number of managerial and professional workers who had been through traumatic redundancies in their late fifties or early sixties reported coming to view retirement more positively - as 'a chance to do other things' (Andrew, IT, sixty-four). A vocational teacher in her early sixties recounted 'feeling very bitter and disappointed with how [her] work life had concluded' after she was retrenched without a farewell party or letter of acknowledgement despite more than twenty years with her employer. In the second interview, she described how she had eventually made a psychological adjustment:

Over the last year I've been able to replace one 'out word' with another 'out word', Redundancy, I feel, is a very negative word whereas retirement opened up all sorts of possibilities. (Trisha, sixty-three)

The ability of these professionals to adapt to redundancy by embracing new dimensions of a life beyond work was aided by the life-course timing of their job loss, with most having sustained careers beyond their mid-fifties. Relatively few were paying a mortgage or living in rental accommodation, and they had generally experienced redundancy at an age when people might previously have been considered to be 'working with retirement in mind' (Ekerdt et al., 2000). Earlier disruptions to career trajectories, by contrast, can have much deeper scarring effects that accumulate over the life-course to significantly narrow people's range of choices in later life. This was highlighted by the experiences of a third group of participants, nearly all of whom had been displaced from stable employment in their forties or very early 50s, leaving them with no choice but 'to keep working and hoping that things will get better' (Rory, community services, fifty-four). As Diane (fifty-two), a former school librarian, who had been in-and-out of casual employment since experiencing redundancy in the mid-1990s, commented:

I want to just keep working a couple of days here, couple of days there. Because, frankly, I haven't any superannuation ... These people who are cashed up and retire, they're very lucky.

The concept of stopping work was largely seen as 'completely fictitious' (Ed, fifty-three) by these participants: a transition reserved for those lucky enough to have sustained continuous careers. Many (two-thirds) were income support recipients who spoke of the 'difference between surviving and living'. A former care-worker receiving the Disability Support Pension elaborated:

I want to live again ... just to be able to go to the pictures one night, not worry about if I go there then I don't eat. (Janine, fifty-one)

There was a sense of lament in their expectations about retirement in that they valued the normative idea of a period of leisure at the end of their working life while seeing it as something they were increasingly less likely to experience. This was reflected in Janine's comment that people, 'especially if they have worked all their life, [are] entitled to a bit of luxury in the end, but I don't see that happening to a lot of us Australian elderly now'. The prospect of retirement was something to be feared; not for how they might fill the void left by work but because, as a long-term unemployed teacher explained, 'if we retire we're moving into total 
poverty basically' (Catherine, fifty-eight). When asked about his retirement expectations, a warehousing worker who had worked intermittently since his thirties responded:

It's a pretty scary proposition. I certainly still haven't any real concept, although sometimes I have said ... 'What is the point of working for the next ten years if it's not even going to come close to making a difference?' I am still going to be living on a pension ... So really having no personal power. If your lease expires and they want you out, you have to go ... So it's not a pretty picture. (Larry, fifty)

As reflected in Larry's concerns about retirement, housing security was a major concern for interviewees in this group. The majority were still paying a mortgage or living in rental accommodation, and some had lost their homes after an extended period of unemployment. An advertising worker who had lost his job during the GFC described his family as living 'on the edge of homelessness' after several years on unemployment benefits:

Everyone has these thoughts of retirement [that] they'll stop work and they'll go and travel and enjoy the grandchildren ... I don't see any of those things on my horizon ... We won't be able to afford that, house ourselves, or eat ... That's a very fearful thing to consider. And it shouldn't be. It should be a time that you enjoy, but it's not something that I look forward to at all. (Ed, fifty-three)

\section{Caught between work and retirement}

Interviewees' accounts of their recent experiences in the labour market suggested that many saw themselves in a kind of Catch-22 situation: on the one hand, they desperately wanted or needed to work, yet, on the other hand, most were pessimistic about finding employment. A software developer who had worked intermittently since the late 1990s described himself as 'semi-retired' on the basis that he didn't 'see getting full-time work at all and [he'd] be lucky to get part-time work' (Jim, fifty-one). Others characterised themselves as 'too young to be old and too old to be young' (Sarah, fifty-eight) or 'professionally unemployed' (Diane, librarian, fifty-two), with many doubting higher pension ages would significantly extend working lives as 'there's a lot of fifty-year olds who are out of work ... and if you can't employ fifty-year olds, you're sure as heck not going to be having a lot of seventy-year olds in the workplace' (Dan, laboratory technician, fifty-three). This sense of being caught between work and retirement was reinforced by repeated unsuccessful attempts in the labour market, which often gave rise to feelings of hopelessness and despair:

It's not being left out, it's being ignored. No one applies for fifty jobs - and you don't even get an answer ... So you feel like you are wasting your time. (Les, telephony worker, sixty-one)

Finnish research into coping with unemployment suggests that the corrosive effects of joblessness on mental health can be aggravated by 'never-ending efforts to penetrate the labour market, which in turn lead to exhaustion and deteriorating mental wellbeing' (Raito and Lahelma, 2015: 14). This finding was underscored by the emotional pain many participants described as accompanying unsuccessful attempts to find work: 
I could understand the circumstances that a lot of those people found who actually took their own lives ... The feeling of not feeling valued is an enormous one ... You can be as brave and have as much bravado as you like and go out there and continually challenge the job market ... But after you've been bashed around the head enough times, it can't [but hurt] you're only human. (Ed, advertising, fifty-three)

An experience recounted by a financial professional was not uncommon:

I've been to see a psychologist for the first time in my life because they reckon I have depression and anxiety ... I suppose it was the pressure of trying to get a job. I mean, I've always had a job! (John, fifty-seven)

A sense of powerlessness about the future pervaded participants' accounts of coping with joblessness and underemployment, with several 'hanging out' for the Age Pension, although, as an administrative worker in her late fifties emphasised: 'I've still got to get to sixty-five, that's the issue' (Sarah, fifty-eight). In the meantime, there was an overriding experience of being 'in the lap of the gods' (Neil, mechanic, fifty-five) or 'lost in limbo' (Sarah, fifty-eight). This was typified by how another administrative worker (who was forced out of her previous long-term job by bullying) described the rest of her life as being 'sort of on hold':

I feel like I'm actually getting exhausted ... My whole focus has become this looking for a job business. I can't even enjoy life because I wake up thinking 'I've got to go and work on that application or something' ... I'm not even going out socially because I'm too scared to spend money because I don't know what the future holds. (Angela, forty-six)

\section{Conclusion}

Although employment rates among older workers are rising in many countries, many older workers continue to experience chronic insecurity in the labour market with rates of long-term unemployment particularly high among mature-age jobseekers. Issues of long-term unemployment and involuntary exit among older workers are not new and were particularly acute during the industrial restructuring of the late-1970s and 1980s. What has changed in the meantime, however, is weakening institutional supports for older workers to retire or leave employment. There is an increasing expectation of current generations of older workers to age 'productively'. As pension ages begin to rise, it is the states' hope that greater numbers will be persuaded to extend the proportion of their lives spent in employment. Yet, as Vickerstaff (2006: 470) argues, any 'analysis of the need for individuals to work for longer and delay retiring must recognise that the majority of individuals may in reality have relatively little personal discretion over the timing and manner of their departure from work'. Indeed, the findings reported here draw attention to an alternative potential manifestation of rising pension ages for a significant minority of older workers on the periphery of employment: a longer period spent in a kind of netherworld between work and retirement.

The netherworld, in ancient mythology, is a place of waiting and suffering, an abyss where people wander aimlessly. A similar sense of pain, fear and uncertainty pervades the experiences of involuntarily exit and underemployment reported here, with participants' stories of repeated unsuccessful attempts to find work highlighting the despair that can accompany involuntary joblessness in mature age, even for managerial and professional workers with a greater degree of choice over whether to retire or try to remain 
in the labour market. Being without work is experienced as a kind of psychological torment by these older workers, and their accounts of suffering depression and anxiety illustrate how the pain of involuntary early exit can be felt particularly acutely by those who 'tend to anchor their identities and values on their working lives and career success' (Gabriel et al., 2013: 58).

Most of those interviewed had little choice over whether to retire or try to continue working. Having become displaced from stable employment in or before their early fifties, retirement was inconceivable for the poverty that it threatened to bring. Their stories of the insecurities and anxieties generated by long-term joblessness and underemployment suggested lives and futures put on hold, and highlighted how the range of risks that older people have to deal with has expanded just as they are expected to work longer (Vickerstaff and Cox, 2005). Their accounts also highlighted the critical significance of the life-course timing of experiences of prolonged joblessness or underemployment for people's prospects, and experiences, of retirement.

Previous studies of early exit have suggested the notion of 'two nations in retirement': the 'middleclass world' of managers and professionals, on the one hand, and 'the working-class world of redundant or early retired manual workers struggling to get by' (Vickerstaff, 2006: 462). However, the participants in this research who were 'struggling to get by' and who had no choice but to try to keep working included not only manual and semi-skilled workers but also several teachers, librarians and other professionals who had been through redundancy in their forties or early fifties followed by many years of un(der)employment at an age when they still had substantial mortgages and other financial commitments. The powerlessness and precariousness that pervaded these participants' descriptions of how their retirement prospects had unravelled demonstrate how the scarring effects of unemployment accumulate over the life-course to constrain opportunities in later life.

As Arulampalam et al. (2001: F577) observe, 'interruptions to employment not only bring the obvious loss of current income during the period of unemployment, but inflict a longer-term 'scar' through the increased future incidence of unemployment and lower subsequent earnings in employment'. Research by Chan and Stevens (2001) using data from the US Health and Retirement Study demonstrates the large and long-lasting employment effects of job loss in mature-age, with just 60 per cent of men and 55 per cent of women finding re-employment two years after a job loss in their mid-fifties. Notably, in Australia, most people who go on to the full Age Pension at sixty-five do so from another income support payment such as Newstart (unemployment) or the Disability Support Pension ${ }^{2}$ (Harmer, 2008: 13; COTA, 2014: 9), suggesting that many of those who become displaced from employment in mature-age struggle to return to work. The Newstart rate of payment is below the 50 per cent median income poverty line (ACOSS, 2014) and has been declining relative to the Age Pension for twenty years (Martin, 2014). For a significant minority of older workers who are un(der)employed, therefore, higher pension ages may compound their experience of a kind of netherworld between work and retirement.

In place of the prevailing focus on extending working lives through higher pension ages, policy initiatives need to be more concretely targeted at the causes of long-term unemployment and underparticipation among those still many years from (current) pension eligibility ages. As highlighted by other contributions to this themed section, this includes developing more robust policy frameworks to combat the pervasiveness of ageism in employment: Riach and Jack (this issue), for example, criticise current 'diversity management' and 'business-case' approaches as being underpinned by an instrumental rationality and of having 'inadvertently become complicit in reproducing age inequality'. It also includes addressing the systemic barriers faced by mature-age clients of public employment services, such as the relative inexperience of many frontline service staff and a prevailing focus on placing clients into low-skilled, entry level work that is out of sync with the skills-sets and experience of many mature-age jobseekers (see Bowman et al., this issue). 


\section{Acknowledgements}

The research for this article was funded by an Australian Research Council Linkage Grant LP120100624. The authors would like to thank the Australian Research Council and project partners, Jobs Australia and the Brotherhood of St Laurence, for their support.

\section{Notes}

1 As Sargent et al. (2013: 6) observe '[w] differentiated than men's', although by the 1970s it had become a distinct life stage for many women too, whether through a shift in their domestic roles and responsibilities upon their husbands' retirement 'or because they themselves retired from paid work'.

2 More than 80 per cent of men and almost 90 per cent of women according to Harmer (2008).

\section{References}

Australian Bureau of Statistics (ABS) (2014) Persons not in the Labour Force September 2013, Cat. 6220.0, Table 6.

Australian Bureau of Statistics (ABS) (2015) Labour Force Australia December 2015, Cat. 6202.0, Table 22.

Australian Council of Social Service (ACOSS) (2014) Poverty in Australia 2014, Surrey Hills, NSW: ACOSS.

Australian Human Rights Commission (2015) National Prevalence Survey of Age Discrimination in the Workplace, Sydney: AHRC.

Arulampalam, W., Gregg, P. and Gregory, M. (2001) 'Unemployment scarring', The Economic Journal, 111, F577-F84.

Chan, S. and Stevens, A. (2001) 'Job loss and employment patterns of older workers', Journal of Labour Economics, 19, 2, 484-521.

Commission of the European Communities (1999) Towards a Europe for all Ages: Promoting Prosperity and Intergenerational Solidarity, Brussels: Commission of the European Communities.

COTA (2014) Submission to the Senate Community Affairs Legislation Committee Inquiry into Social Services and Other Legislation Amendment (2014 Budget Measures No. 1), Bill 2014 and the Social Services and Other Legislation Amendment (2014 Budget Measures No.2), July 2014.

Department of Employment (2015a) Job Services Australia Data June 2015-Mature-Age Population by Duration of Registration, http://lmip.gov.au/PortalFile.axd?FieldID=1453530.

Department of Employment (2015b) Job Services Australia Data June 2015-Newstart Customer Population By Age Group, http://lmip.gov.au/default.aspx?LMIP/EmploymentData_ JobServicesAustraliaNewstartRecipientsbyAge.

Department of Social Services (2009) Income Support Customers: A Statistical Overview 2008, www. dss.gov.au/about-the-department/publications-articles/research-publications/statistical-paper-series/ statistical-paper-no-7-income-support-customers-a-statistical-overview-2008.

Ekerdt, D. (2010) 'Frontiers of research on work and retirement', Journal of Gerontology: Social Sciences, 65B, 1, 69-80.

Ekerdt, D., Kosloski, K. and Deviney, S. (2000) 'The normative anticipation of retirement by older workers', Research on Aging, 22, 1, 3-22.

Farrel, L. (2014) Unretirement, London: Bloomsbury Press.

Freedman, M. (2006-07) 'The social-purpose encore career', Generations, 30, 4, 43-6. 
Gabriel, Y., Gray, D. and Goregaokar, H. (2013) 'Job loss and its aftermath among managers and professionals', Work, Employment and Society, 27, 1, 56-72.

Guest, G., Bunce, A. and Johnson, L. (2006) 'How many interviews are enough? An experiment with data saturation and variability', Field Methods, 18, 1, 59-82.

Guillemard, A.-M. (1997) 'Re-writing social policy and changes within the life course organisation: a European perspective', Canadian Journal on Ageing, 16, 3, 441-64.

Han, S. and Moen, P. (1999) 'Clocking out: temporal patterning of retirement', American Journal of Sociology, 105, 1, 191-236.

Harmer, J. (2008) Pension Review, Background Paper, Canberra: Department of Families, Housing, Community Services and Indigenous Affairs.

Havinghurst, R. (1954) 'Flexibility and the social roles of the retired', American Journal of Sociology, 59, 4, 309-11.

Hershey, D. A. and Henkens, K. (2013) 'Impact of different types of retirement transitions on perceived satisfaction with life', The Gerontologist, 54, 2, 232-44.

Johnson, R. W. (2012) Older Workers, Retirement, and the Great Recession, Palo Alto: The Russell Sage Foundation and the Stanford Centre on Poverty and Inequality, https://web.stanford. edu/group/recessiontrends/cgi-bin/web/sites/all/themes/barron/pdf/Retirement_fact_sheet.pdf.

Kohli, M. and Rein, M. (1991) 'The changing balance of work and retirement', in M. Kohli, M. Rein, A.-M. Guillemard and H. Van Gunsteren (eds.), Time for Retirement, Cambridge: Cambridge University Press, 1-35.

Martin, P. (2014) 'Newstart recipients falling behind as age pension nears $\$ 20,0000$ ', Sydney Morning Herald, 24 March 2014.

McDaniel, S. and Bernard, P. (2011) 'Life-couse as a policy lens', Canadian Public Policy, 37, Supplement, S1-S13.

McDonald, L., Donahue, P. and Moore, B. (2000) 'Retirement through unemployment', Canadian Social Work Review, 17, 1, 69-85.

McGann, M., Bowman, D., Kimberley, H. and Biggs, S. (2015) Too Old to Work, Too Young to Retire, Melbourne: Brotherhood of St Laurence, http://library.bsl.org.au/jspui/bitstream/1/ 7905/4/Workforce_vulnerabilities_in_midlife_and_beyond_research_summary_2015.pdf.

McNair, S. (2006) 'How different is the older labour market? Attitudes to work and retirement among older people in Britain', Social Policy and Society, 5, 4, 485-94.

Moody, H. (2008) 'Aging America and the boomer wars', The Gerontologist, 48, 6, 839-44.

Organisation for Economic Cooperation and Deveopment (OECD) (1998) Maintaining Prosperity in an Ageing Society, Paris: OECD.

Parry, J. and Taylor, R. (2007) 'Orientation, opportunity and autonomy: why people work after state pension age in three areas of England', Ageing and Society, 27, 579-98.

Phillipson, C. (2013) 'Reconstructing work and retirement: labour market trends and policy issues', in J. Field, R. Burke and C. Cooper (eds.), The Sage Handbook of Ageing, Work and Society, London: SAGE, 445-60.

Phillipson, C. (2015) 'The political economy of longevity: developing new forms of solidarity for later life', The Sociological Quarterly, 56, 1, 80-100.

Raito, P. and Lahelma, E. (2015) 'Coping with unemployment among journalists and managers', Work, Employment and Society, 29, 5, 720-37.

Ranzijn, R., Carson, E., Winefield, A. and Price, D. (2006) 'On the scrap-heap at 45: the human impact of mature-aged unemployment', Journal of Occupational and Organizational Psychology, 79, 3, 467-79. 
Sargent, L., Lee, M., Martin, B. and Zikic, J. (2013) 'Reinventing retirement: new pathways, new arrangements, new meanings', Human Relations, 66, 1, 3-21.

Shultz, K. and Wang, M. (2011) 'Psychological perspectives on the changing nature of retirement', American Psychologist, 66, 3, 170-9.

Taylor, P. (2010) 'Cross-national trends in work and retirement', in D. Dannefer and C. Phillipson (eds.), The SAGE Handbook of Social Gerontology, California, Sage, 540-50.

Taylor, P. (2013) 'Introduction', in P. Taylor (ed.), Older Workers in an Ageing Society, Northampton, MA: Edward Elgar Publishing, 1-18.

Vickerstaff, S. (2006) "'I'd rather keep running to the end and then jump off the cliff": retirement decisions - who decides?', Journal of Social Policy, 35, 3, 455-72.

Vickerstaff, S. (2010) 'Older workers: the "unavoidable obligation" of extending our working lives?', Sociology Compass, 4, 10, 869-79.

Vickerstaff, S. and Cox, J. (2005) 'Retirement and risk: the individualisation of retirement experiences?', Sociological Review, 53, 1, 77-95.

Warren, D. (2008) Retirement Expectations and Labour Force Transitions: The Experience of the Baby Boomer Generation, Melbourne: Melbourne Institute of Applied Economics. 
Reproduced with permission of the copyright owner. Further reproduction prohibited without permission. 